\title{
Abundance, encystment and sedimentation of acantharia during autumn 1990 in the East Greenland Sea
}

\author{
Avan N.Antia, Eduard Bauerfeind, Bodo v.Bodungen and Ute Zeller \\ SFB 313 der Universität Kiel, Heinrich Hecht Platz 10, Olshausenstraße 40, 2300 \\ Kiel, FRG
}

\begin{abstract}
The abundance and sedimentation of acantharia and their cysts was recorded in the water column and sediment traps in the East Greenland Sea in August-September 1990. Although acantharia constituted $<1 \%$ of total suspended particulate organic carbon (POC) in the water column, up to $90 \%$ (average $55 \%$ ) of the $P O C$ sedimenting in $100 \mathrm{~m}$ was present in the form of acantharian cysts during a 9 day drift experiment. Rapid dissolution of strontium sulphate, of which their shells and spines are constructed, was evidenced by their disappearance with depth in the water column, maximum dissolution occurring between 500 and $1000 \mathrm{~m}$ water depth. Mass encystment and sedimentation of this single group of sarcodine protozoa can have dramatic effects on, the measurement of particulate fluxes in the open ocean, and may be a recurrent phenomenon in the eastern North Atlantic.
\end{abstract}

\section{Introduction}

Although the acantharia, a group of the sarcodine protozoa, have been recognized since the turn of the century (Haeckel, 1887; Schewiakoff, 1902), a more detailed study of their trophic behaviour has only recently received renewed attention (Michaels, 1991; Swanberg and Caron, 1991). Previously grouped among the radiolaria due to their structural similarity, they are distinguished by the celestite composition of their spicules and cyst walls. In marine environments, they are the only organisms known to precipitate strontium from the dissolved form. Since seawater is undersaturated in strontium sulphate, these hard parts dissolve rapidly upon the death of the organisms, maximal dissolution occurring between 300 and $900 \mathrm{~m}$ water depth (Bernstein et al., 1987). For this reason, acantharia have rarely been reported in sedimenting material and are seldom preserved in plankton samples; they are absent in bottom sediments and have left no trace in the geological record. Numerically, acantharia often exceed radiolaria and foraminifera in the euphotic zone (Beers and Stewart, 1971; Bottazzi and Andreoli, 1982) and, by virtue of their algal symbionts (Michaels, 1991) and grazing activity (Swanberg and Caron, 1991), may play a dominant role in the upper water layers. Bernstein et al. (1987), measuring strontium in the water column and sediment traps, were able to identify a surface depletion in strontium in the North Pacific during a time of high acantharian abundance showing that, by the uptake of celestite in shallow waters and its release at depth, these organisms may play an important role in the strontium budget of the oceans.

We report here, however, on standing stocks of acantharia and their contribution to the vertical flux of organic matter. The composition of biogenic material sedimenting out of the euphotic zone to some extent reflects seasonally important processes in the productive layers, and its diminution with depth is 
related to degradation and alteration patterns in mid-water layers. A high seasonal variability in the annual patterns of vertical flux is often accounted for by the foraging activity of distinct groups of 'swarmer' organisms such as krill (v.Bodungen, 1986; v.Bodungen et al., 1987), salps (Bathmann, 1988) and pteropods (Bathmann et al., 1991). The acantharia may form another distinct group which by virtue of their reproductive cycle and cyst formation affect the mass sedimentation of organic matter from the euphotic zone.

We report here on the abundance of vegetative acantharia and their cysts, both in the water column and sediment trap samples, during autumn 1990 in the East Greenland Sea during the cruise POSEIDON 173/2 as part of the Special Research Project (Sonderforschungsbereich) 313 of the University of Kiel, - FRG.

\section{Method}

Investigations were conducted in the water column and using sediment traps in the East Greenland Sea at and near the position of a long-term deployment at $72^{\circ} 00.2^{\prime} \mathrm{N}, 07^{\circ} 02.5^{\prime} \mathrm{W}$. Sediment traps in this mooring were positioned at 500 , 1000 and $2000 \mathrm{~m}$ water depth. A drifting (between $72^{\circ} 37^{\prime}$ and $72^{\circ} 19^{\prime} \mathrm{N}$ and $7^{\circ} 33^{\prime}$ and $7^{\circ} 30^{\prime} \mathrm{W}$ ) sediment trap array with traps in 100 and $300 \mathrm{~m}$ was deployed from 24 August to 1 September. Between 24 August and 1 September, a mooring at $72^{\circ} 00.7^{\prime} \mathrm{N}, 07^{\circ} 02.5^{\prime} \mathrm{E}$ was equipped with sediment traps at $100,500,1000$ and $2000 \mathrm{~m}$.

A new design of the Kiel sediment trap, as originally described by Zeitzschel et al. (1978), was used in all deployments with sample jars containing seawater of increased salinity and $\mathrm{HgCl}_{2}$ (to a final concentration of $0.07 \%$ ) as a poison. Samples were collected over $24 \mathrm{~h}$ intervals in both the traps of the drifting array and at $100 \mathrm{~m}$ in the short-term mooring; a single jar collected an integrated sample over the 9 day deployment period at 500,1000 and $2200 \mathrm{~m}$ in the shortterm mooring.

Prior to the treatment of sediment trap samples, swimmers were gently removed with a pipette and rinsed free of adhering material. From the drifting traps and those of the short-term mooring, a small aliquot was withdrawn from each collection cup and used for light microscopy on board. This aliquot was then stored at $4^{\circ} \mathrm{C}$ for later analysis by scanning electron microscopy (SEM, Cambridge $150 \mathrm{~B}$ ). The samples were then split into aliquots of $1 / 16$ to $1 / 32$ on board and were stored refrigerated until further analysis. Parallel splits were filtered onto GF/F filters and stored frozen for further analysis of dry weight and particulate organic carbon (POC) in the laboratory. A detailed report on the methods and procedures of analysis "of our sediment trap samples has been published by v.Bodungen et al. (1991).

Samples from the water column were taken by means of a multiple opening and closing net (mesh size $100 \mu \mathrm{m}$, opening $0.25 \mathrm{~m}^{2}$ ). The net was towed vertically through the water column and samples were taken from $500 \mathrm{~m}$ to the surface at five different depth intervals. Samples were fixed with borax-buffered formaldehyde (final concentration $4 \%$ ) on board. On return to the laboratory, and confirmation of the celestite structure of the cysts 6-8 weeks later, 
$\mathrm{SrCl}_{2} \cdot 6 \mathrm{H}_{2} \mathrm{O}$ to a final concentration of $80 \mathrm{mg} \mathrm{I}^{-1}$ was added to both water column and sediment trap samples, in order to prevent further dissolution of acantharian skeletons and cyst walls, as recommended by Beers and Stewart (1970). Acantharia and their cysts were counted using a binocular microscope under $\times 25$ magnification. Net samples from near-surface probes were split (onetenth to four-tenths) prior to enumeration, whereas those from deeper layers were counted whole. Several hundred cysts were gently transferred from the deep-frozen samples onto replicate GF/F filters for subsequent determinations of dry weight and carbon content. For the determination of dry weight, each filter was rinsed three times with deionized water, counted, dried at $60^{\circ} \mathrm{C}$ for $12 \mathrm{~h}$ and then reweighed. POC was measured by high-temperature combustion with a Hereaus Rapid CHN-O analyser. This measured POC value was used in conversions of cyst number to biomass for all samples.

\section{Observations and results}

\section{Microscopic observations}

EDAX analysis (EDAX B) of several cysts revealed them all to have walls composed of $\mathrm{SrSO}_{4}$ (Figure 2e), confirming that they belong to the acantharia. Scanning electron microscopy showed that the cyst wall was porous and irregular in structure, and not constructed of individual plates, as has been reported for some species of acantharia (Hollande et al., 1965; Spindler and Beyer, 1990). The shafts of spines appeared to be laterally flattened and star-shaped in crosssection with smooth edges (Figure $2 b$ ). In some cases, the cytoplast of the acantharian with remnants of spines was visible within broken cysts (Figure 2c and d), a fact that was also noticed by Spindler and Beyer (1990). Both the vegetative forms and cysts that we found appeared to belong to the same family of acantharia. Round cysts of acantharia with differing diameters and surface structures have often been reported in the literature. The form seen in this study appear similar to, although smaller than, those reported by Spindler and Beyer (1990; their plate III). A similar cyst has been observed in sediment traps from the Canadian Arctic (Hargrave et al., 1992).

Net tows in the upper 50-100 m revealed acantharia of the same species, but exhibiting differing forms with respect to the appearance of an extracapsular membrane, the degree of deposition of strontium sulphate on the cyst wall as well as the degree of resorption of the spines (Figure 1). Light microscopy of live samples in a Petri dish on board ship showed numerous vegetative individuals with compact, rotund cell bodies $-75-100 \mu \mathrm{m}$ in diameter, containing numerous (30-50) reddish-coloured droplets. Twenty radially divergent spines $\sim 150-250 \mu \mathrm{m}$ in length were seen protruding from a central axis, arranged according to the Müllerian law (Figure 1a). In many individuals a transparent mucous envelope surrounded the cell body, from which the spines protruded, these spines showed some signs of dissolution (Figure 1b). Deposition of celestite on this membranous covering was seen in many specimens, with the spines protruding through the openings in the cyst wall; these appeared to be early forms of the cysts in the water column. Further deposition of celestite 

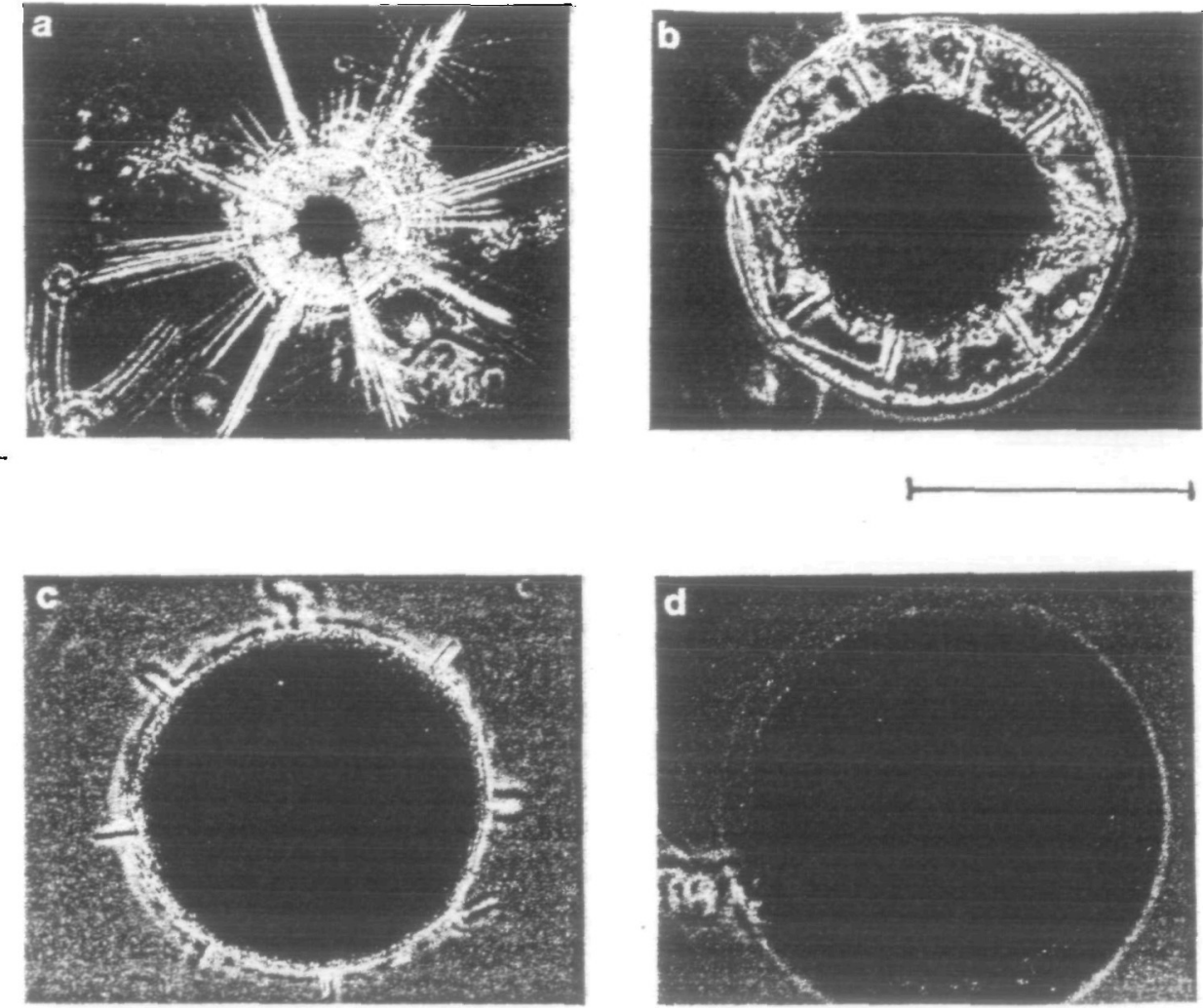

Fig. 1. Light micrographs showing acantharia in different stages of encystment. Scale bar $=200 \mu \mathrm{m}$. (a) Vegetative acantharian with intact spines. (b) A mucous envelope surrounds the cytoplasm, through which the spines protrude. (c) The cyst wall is no longer opaque due to deposition of strontium on the mucous matrix. (d) Cyst with dissolved spines. The pores through which the spines protruded are still visible.

forms a cyst wall $\sim 5-7 \mu \mathrm{m}$ in thickness, within which the cell body is enclosed, with few remaining spines (Figure 1d); these were the primary forms of cysts found in the sediment traps. This cyst wall is thickened and slightly elevated around the openings through which the spines protruded (Figure $2 a$ and $b$ ). As it is known that acantharians resorb the spines during cyst formation (Schewiakoff, 1926; Hollande et al., 1965; Bottazzi, 1973), it is likely that cysts possessing spines represent freshly produced cysts in which the process of spine resorbtion was not completed, whereas cysts without any spines may represent a more advanced developmental stage. Acantharians are known to be susceptible to damage by net collections, which can lead to spontaneous resorbtion of spines, which severely comprises observations based on these samples. Our data, however, clearly indicate an actively encysting population in the water column, and we were able to observe numerous individuals of the various forms described above, leading us to suppose that these may be stages in the encystment process of these organisms. However, laboratory observations of 

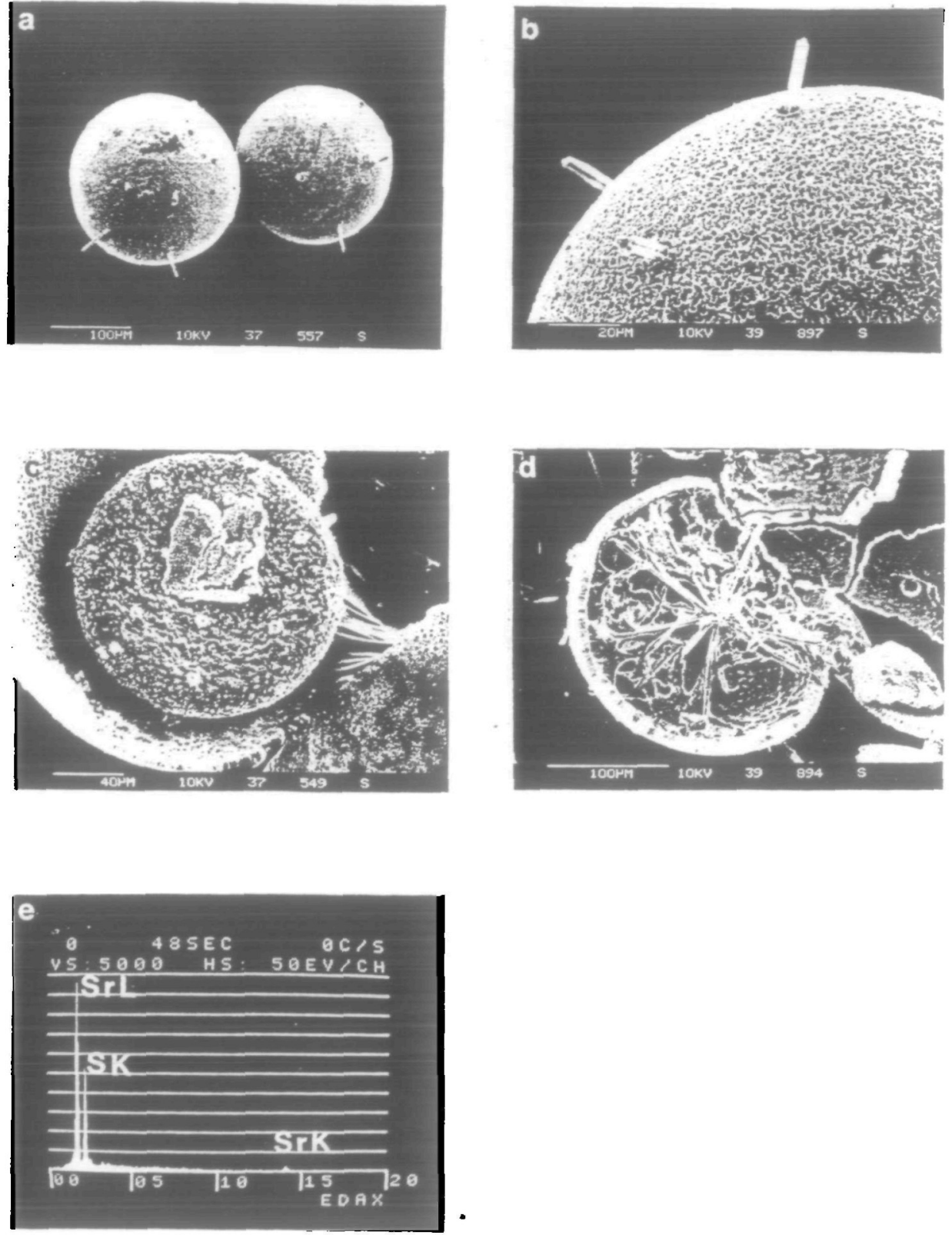

Fig. 2. Scanning electron micrographs of acantharian cysts. (a) Overview of round cysts with remnants of spines. (b) Surface of a cyst, showing irregular structure. Spines protrude from pores with elevated rims. (c) A cyst broken open, to show the cytoplast of the acantharian. Absorption of the spines is almost complete. (d) A broken cyst, with the inner part of the cytoplasm visible. Spines are arranged in a radial fashion around a central axis. (e) EDAX (EDAX B) analysis of cyst walls. 
encysting acantharia are necessary in order to achieve detailed information on the encystment process.

Cyst formation in acantharia has been incompletely studied, partly due to the difficulty in maintaining these protozoans in culture, and the rapid dissolution of $\mathrm{SrSO}_{4}$ after their death. In their review of acantharian encystment, P.C. Ried and A.W.John (unpublished manuscript) recorded that encystment is seen to precede or accompany sporogenesis, forming a vital process in the reproductive cycle of acantharia (also Hollande and Cachon-Enjumet, 1957). Fission of nuclei within the cyst results in the formation of spores, which are thought to emerge during excystment from the pores left after dissolution of the spines. Hollande et al. (1965) described these spores as oval or elongated biflagellate cells $\sim 10 \mu \mathrm{m}$ in diameter, apparently indistinguishable by light microscopy from other small flagellates. We did not observe the excystment process in live material and were unable to identify acantharian spores in our plankton samples.

\section{Distribution in the water column}

Samples from net tows in the upper $500 \mathrm{~m}$ were counted for vegetative acantharia and cysts at three stations along the path of the drifter. Numbers of vegetative acantharia ranged from 2554 ind. $\mathrm{m}^{-3}$ on 25 August to 1843 ind. $\mathrm{m}^{-3}$ on 1 September along this transect (Figure 3 ) and were almost exclusively (>96\% of all cells) confined to the upper $50 \mathrm{~m}$ of the water column, with no individuals found below $100 \mathrm{~m}$. These values lie within the range of acantharia found in the North Pacific (3000-4000 ind. $\mathrm{m}^{-3}$; Michaels, 1991) and Atlantic Ocean (1000-4000 ind. $\mathrm{m}^{-3}$; Michaels, 1988). Bottazzi and Vannucci (1965), using extensive net tows, found somewhat lower abundances of $0-40$ ind. $\mathrm{m}^{-3}$ in the upper $200 \mathrm{~m}$ in the Atlantic. Integrated abundances of vegetative forms (0$100 \mathrm{~m}$ ) in this study ranged from 1.2 to $3.5 \times 10^{5} \mathrm{~m}^{-2}$. Our numbers however, may represent minimum counts as net tows are thought to severely underestimate plankton abundances (Michaels, 1988). Additionally, since $\mathrm{SrCl}_{2}$ was added to the samples 6-8 weeks after collection, some dissolution may have occurred by that time.

A near-surface maximum of acantharians is a well-known feature and has been reported from different areas of the ocean (Bottazi and Vannucci, 1965; Bishop et al., 1977; Michaels, 1988). Vegetative acantharia are known to have a mechanism that enables them to control their buoyancy in the water column (Schewiakoff, 1902; Cachon and Cachon, 1985). Their confinement to surface layers, often within the upper $20 \mathrm{~m}$, provides the autotrophic symbionts that the acantharia are known to possess with optimal light conditions for photosynthesis. During the period of our study, light penetration was confined to the upper $40-50 \mathrm{~m}(0.1 \%$ light level) of the water column. Integrated daily primary production rates in the euphotic zone (as measured by ${ }^{14} \mathrm{C}$ incorporation) averaged $150 \mathrm{mg} \mathrm{C} \mathrm{m}^{-2} \mathrm{day}^{-1}$, a factor of three lower than those measured at an adjacent station during June-July 1989. If acantharian photosymbionts enhanced their growth, this is likely to have been taking place at a slow rate.

Cysts were counted in two size classes, $<200$ and $\geq 200 \mu \mathrm{m}$, the latter being 

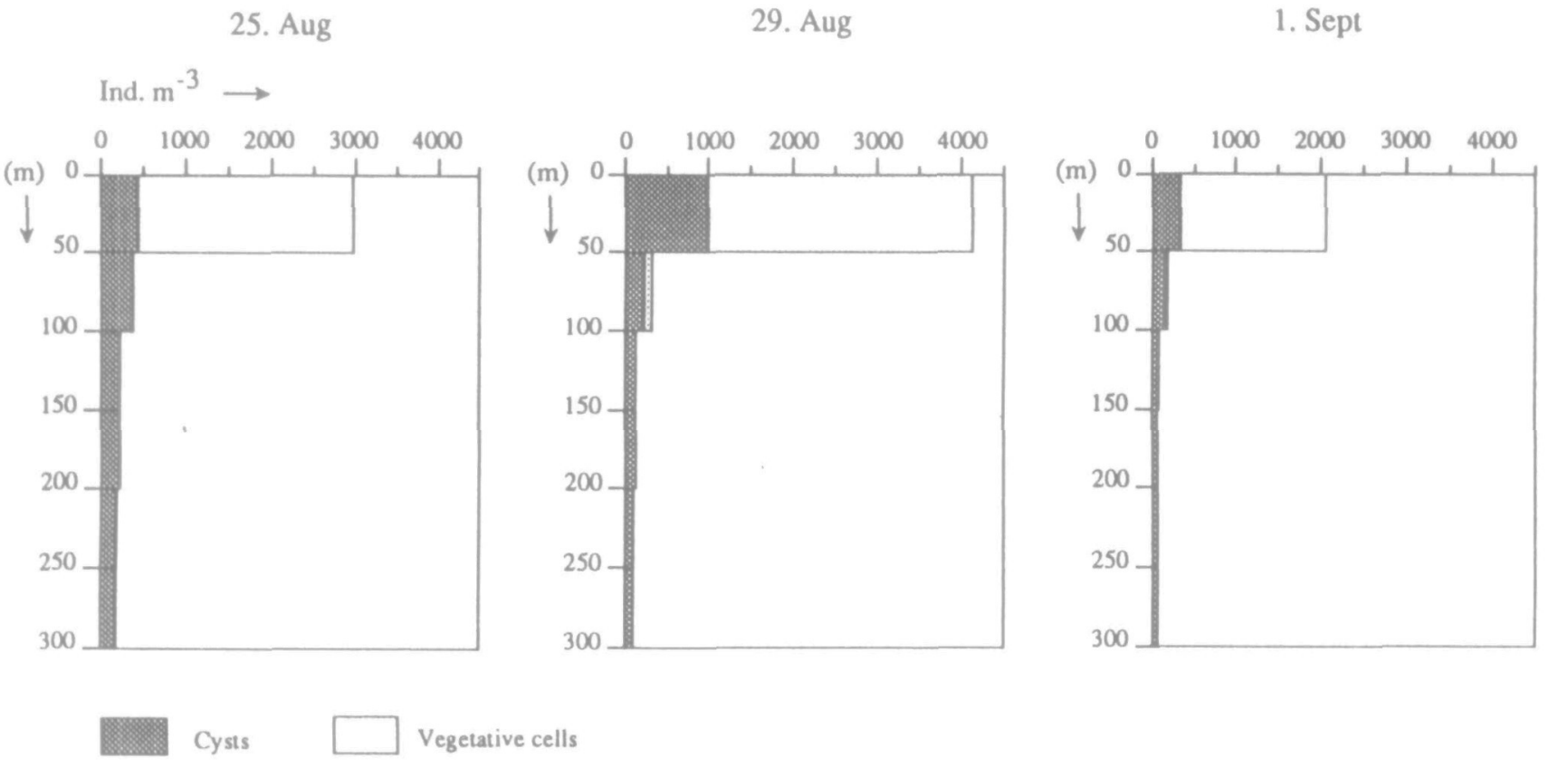

Fig. 3. Vertical profiles of vegetative acantharia and cysts at three stations along the path of the drifting array. $X$-axis values indicate the depth intervals of net tows. 
dominant ( $>70 \%$ of total number) in all samples. Numbers of cysts were highest in the upper $50 \mathrm{~m}$ of the water column at between 434 and 986 ind. $\mathrm{m}^{-3}$, decreasing to $<68-171$ ind. $\mathrm{m}^{-3}$ by $300 \mathrm{~m}$. This depth distribution differs from reports in the literature where maximum cyst numbers occur between 100 and $300 \mathrm{~m}$ (Hollande et al., 1965; Bottazzi, 1973; Spindler and Beyer, 1990). The integrated abundance of cysts in the upper $300 \mathrm{~m}$ of the water column varied from an initial $0.79 \times 10^{5}$ to $0.4 \times 10^{5} \mathrm{~m}^{-2}$ at the end of the study. Active encystment of vegetative cells appeared to at least partially balance their loss by dissolution and sinking, which was further borne out by our microscopic analysis, showing numerous 'freshly produced' cysts with remnants of spines still attached.

We were able to measure an average dry weight and organic carbon content of $5.17 \pm 0.28 \mu \mathrm{g}$ and $0.3284 \pm 0.02 \mu \mathrm{g} \mathrm{C}$ per cyst, respectively $(n=3$ filters containing 57,85 and 155 cysts). We measured an average cyst diameter of $234 \pm$

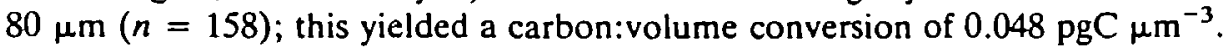
This factor is lower than that for the central capsule of acantharia of 0.08 used by Beers et al. (1975), which is to be expected as the internal volume of cysts was not entirely filled with cytoplasm. We used the value of Beers $e t$ al. (1975) and a measured capsule diameter of $100 \mu \mathrm{m}$ (Figure 1a) to calculate a carbon content of $0.04 \mu \mathrm{g} \mathrm{C}$ per vegetative acantharia; and were thus able to estimate the contribution of both cysts and vegetative cells to total POC in the upper $100 \mathrm{~m}$ of the water column. Acantharian cysts accounted for $50-323 \mu \mathrm{g} \mathrm{C} \mathrm{m}^{-3}$ and vegetative cells for $2-126 \mu \mathrm{g} \mathrm{C} \mathrm{m}{ }^{-3}$, corresponding to a total contribution of $0.05-0.31 \%$ of water column POC. Integrated biomass values of vegetative cells in the upper $50 \mathrm{~m}$ of $3.38-6.3 \mathrm{mg} \mathrm{C} \mathrm{m} \mathrm{m}^{-2}$ are comparable to, although lower than, those found by Michaels (1991) in the North Pacific $\left(6.8-56.7 \mathrm{mg} \mathrm{C} \mathrm{m}^{-2}\right)$. During an 18 month investigation, Michaels (1991) found a constant presence of acantharia in the euphotic zone, with the highest abundances in summer and autumn. We have no data on the seasonal patterns of acantharia at our station and only indirect evidence of their abundance via cysts in the annual mooring, the interpretation of which is severely compromised by dissolution problems.

\section{Cyst sedimentation}

The patterns of daily cyst sedimentation in traps at 100 and $300 \mathrm{~m}$ are shown in Figure 4, from which it is evident that large cysts $(>200 \mu \mathrm{m})$ dominated in both depths. This reflects the size distribution of cysts in the water column and may be enhanced by the higher sinking velocity of larger forms. In the drifting trap array, cyst numbers at $100 \mathrm{~m}$ were higher during the first half of the deployment period, reaching a maximum of 112800 ind $\mathrm{m}^{-2} \mathrm{day}^{-1}$. The total flux within the 9 day period amounted to 575361 cysts $\mathrm{m}^{-2}$, yielding a mean sedimentation rate of 69377 cysts $\mathrm{m}^{-2}$ day $^{-1}$. This decreased by $\sim 50 \%$ in $300 \mathrm{~m}$, due to loss by dissolution and excystment, with a mean sedimentation of 34380 cysts $\mathrm{m}^{-2}$ day $^{-1}$. The relative contribution of acantharian POC to total POC in the sampling jars of traps in $100 \mathrm{~m}$ showed a decreasing trend during the time of this study. Acantharian cysts contributed between 74 and $92 \%$ of total sedimenting 


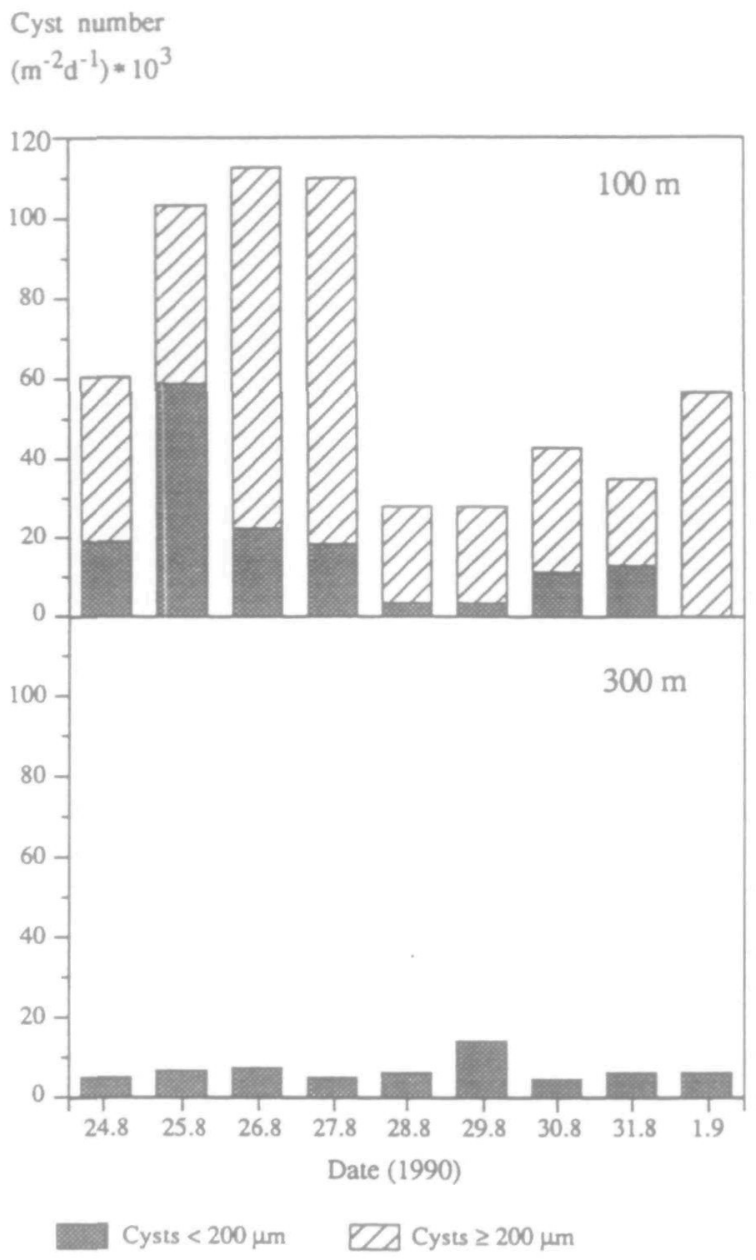

Fig. 4. Daily sedimentation rate of acantharian cysts in drifting sediment traps at 100 and $300 \mathrm{~m}$.

POC between 24 and 26 August; this decreased to $\sim 30 \%$ of total POC during the latter half of the study. Averaged over the 9 days, $55 \%$ of total sedimenting POC in $100 \mathrm{~m}$ was accounted for by acantharia. In $300 \mathrm{~m}$, this decreased to a mean value of $36 \%$ of the total sedimenting POC.

A short-term mooring which was anchored close to the starting position of the drifter yielded data on the sedimentation of acantharian cysts to deeper waters (Figure 5). Cyst numbers in the trap in $100 \mathrm{~m}$ of this mooring were somewhat lower than those encountered at $100 \mathrm{~m}$ in the drifter and accounted for $32 \%$ of total sedimenting POC at this depth (Table I). This value decreased almost 5fold in $500 \mathrm{~m}$, and represented 1 and $<0.1 \%$ of total sedimenting POC in 1000 and $2000 \mathrm{~m}$, respectively. In terms of dry weight, the contribution of acantharian cysts was similarly high, amounting to $59,11,3$ and $0.1 \%$ of total sedimenting matter at 100, 500, 1000 and $2200 \mathrm{~m}$, respectively. Rapid dissolution of cyst walls 
A.N.Antia et al.

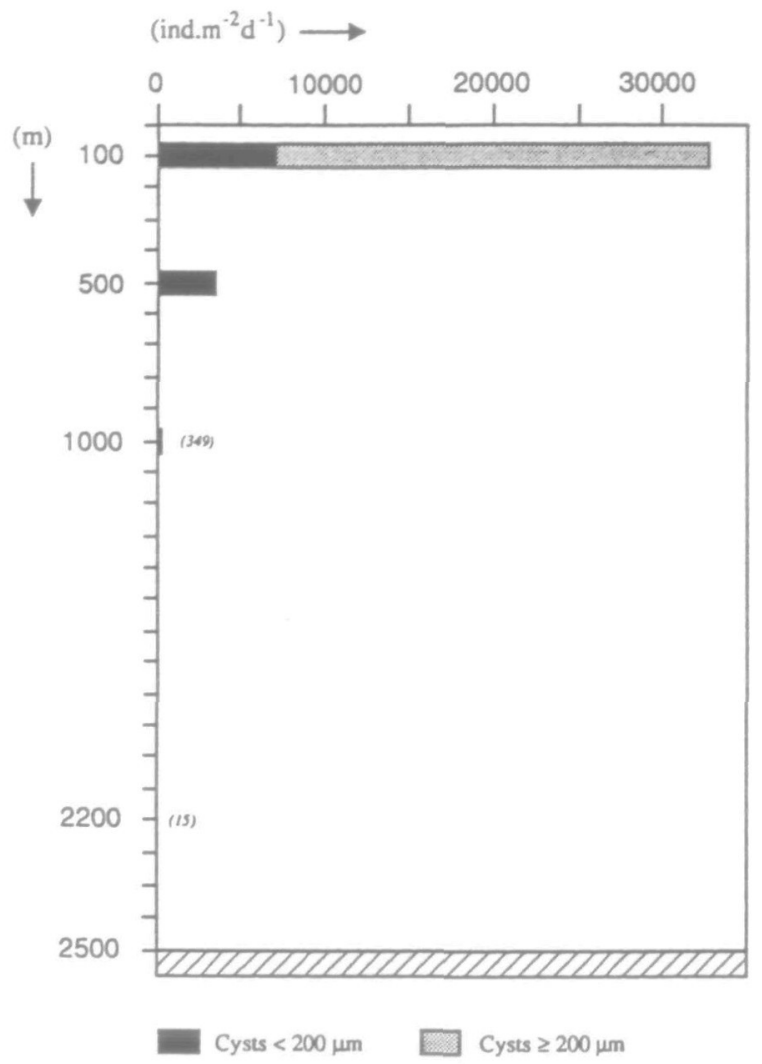

Fig. 5. Daily sedimentation rate of acantharian cysts in the short-term mooring deployed from 24 August to 1 September 1990 . The $X$-axis indicates the depth of trap deployment.

Table I. Total dry weight (DW) and particulate organic carbon (POC) fluxes in sediment traps of the short-term mooring deployed from 24 August to 1 September 1989 in the Greenland Sea. The contribution of acantharia to dry weight (Ac-DW) and POC (Ac-POC) has been calculated from cyst numbers using measured conversion factors. All values are expressed as $\mathrm{mg} \mathrm{m}^{-2}$ day $^{-1}$

\begin{tabular}{ccccccc}
\hline $\begin{array}{l}\text { Depth } \\
(\mathrm{m})\end{array}$ & Total DW & Ac-DW & (\% total DW) & Total POC & Ac-POC & (as \% total POC) \\
\hline 100 & 286.3 & 169.5 & 59 & 33.85 & 10.8 & 32 \\
500 & 146.0 & 16.6 & 11 & 22.29 & 1.2 & 5 \\
1000 & 82.94 & 2.17 & 3 & 14.93 & 0.13 & 0.9 \\
2200 & 59.06 & 0.09 & 0.1 & 7.62 & 0.005 & $<0.1$ \\
\hline
\end{tabular}

has often been reported between 400 and $900 \mathrm{~m}$ water depth (Hollande et al., 1965; Bernstein et al., 1987; Spindler and Beyer, 1990) and is in accordance with our data. The contribution of acantharian cysts to sedimenting POC in our study far exceeds that by vegetative cells ( $9 \%$ ) reported by Michaels (1991) at the base of the euphotic zone.

108 
Abundance, encystment and sedimentation of meantharia

Table II. Sedimentation of acantharian cysts (ind. $m^{-2}$ day ${ }^{-1}$ ) in sediment traps of the long-term mooring in the Greenland Sea

\begin{tabular}{lccc}
\hline Sampling interval & $500 \mathrm{~m}$ & $1000 \mathrm{~m}$ & $2200 \mathrm{~m}$ \\
\hline $15.07-01.08 .89$ & \multicolumn{10}{c}{} & 16 & 0 \\
$02.08-15.08 .89$ & 1119 & 163 & 0 \\
$16.08-01.09 .89$ & 2158 & 401 & 0 \\
$02.09-15.09 .89$ & 268 & 16 & 0 \\
$16.09-30.09 .89$ & 0 & 0 & 0 \\
Up to 01.08 .90 & 0 & 0 & 0 \\
\hline
\end{tabular}

- Sample lost.

The collection efficiency of sediment traps has been repeatedly questioned, and places limitations on the interpretation of their data. Buesseler (1991) reports a significant and random collection bias in the collection efficiency of shallow traps deployed for short periods. An additional recognized problem, especially in deployments within the upper water layers, is the influence of socalled 'swimmers'. The sediment traps we use are funnel/cone shaped with a baffle-aspect ratio of $5: 1$, with an opening of $\sim 0.5 \mathrm{~m}^{2}$. We cannot exclude a collection bias of the traps used in this study, but it is likely that large, fastsinking particles such as the cysts reported here are adequately sampled by the traps. Large macrozooplankton swimmers are removed prior to the analysis of particulate material and are not included in POC and dry weight measurements.

From an examination of the samples of our long-term annual mooring in the East Greenland Sea, we have indications that encystment and sedimentation of acantharia may be a recurring event in this part of the North Allantic (Table II). A small number of cysts were found in preserved samples between the middle of July 1989 and September 1989 down to $1000 \mathrm{~m}$ water depth. These appeared, on microscopic analysis, to be the same form of cysts as those encountered in 1990. We view these values, at best, as minimum estimates due to the problems of dissolution mentioned above, and the long time interval between sample collection and analysis. However, dissolution of cysts in the sampling jars may elevate $\mathrm{Sr}$ levels, slowing the process and allowing for some preservation in longterm moorings. The value of 2158 ind. $\mathrm{m}^{-2}$ day $^{-1}$ at $500 \mathrm{~m}$ between 16 August and 1 September 1989 is nonetheless comparable to that found at $500 \mathrm{~m}$ in the short-term mooring deployed during this study. It is possible that cyst dissolution may have masked a much larger (and longer) acantharian sedimentation event. On subsequent cruises, we have observed acantharians and cysts in net hauls from the northern North Atlantic in the Barents and Norwegian Seas, and in shallow sediment traps during April/May 1992 at $47^{\circ} \mathrm{N}, 20^{\circ} \mathrm{W}$. The measurement of dissolved and particulate strontium in the sampling jars of sediment traps may be useful in order to follow the seasonal patterns of occurrence and sedimentation of acantharia.

We measured a potential sinking rate of $238( \pm 96) \mathrm{m} \mathrm{day}^{-1}$ (range 103-367; $n=13$ ) of cysts in the laboratory by timing their descent in a measuring cylinder $\left(80 \mathrm{~cm}\right.$ long, $10 \mathrm{~cm}$ diameter, filled with filtered seawater at $\left.6^{\circ} \mathrm{C}\right)$. This value 
closely approximates their potential sinking speed of $216 \mathrm{~m}$ day $^{-1}$ as calculated from Stokes Law (using a mean diameter of $200 \mu \mathrm{m}$ and the measured weight of $5.17 \mu \mathrm{g} \mathrm{cyst}^{-1}$ ). It was further possible to calculate a sinking rate for cysts independent of the traps. Integrated cyst abundance in the upper $100 \mathrm{~m}$ amounted to $25000-62000$ ind. $\mathrm{m}^{-2}$. This agrees well with the values of 27000 110000 ind. $\mathrm{m}^{-2}$ found in the traps at $100 \mathrm{~m}$. Similarly, integrated abundances between 150 and $300 \mathrm{~m}$ of $30600-83100$ ind. $\mathrm{m}^{-2}$ correspond to cyst numbers of $18000-51000$ ind. $\mathrm{m}^{-2}$ found in the trap at $300 \mathrm{~m}$. This would indicate a sedimentation rate of between 100 and $150 \mathrm{~m}_{\text {day }}{ }^{-1}$, somewhat lower than the theoretical value. The observed pattern of sedimentation cannot therefore be explained purely in terms of sinking processes. The peak in sedimentation at $-100 \mathrm{~m}$ between 25.8 and 27.8 , and its absence at $300 \mathrm{~m}$, as well as the $20 \%$ decrease in numbers between these depths, indicate that other loss processes need to be accounted for. Although losses due to grazing pressure and horizontal advection cannot be guled out, we suggest that dissolution and, perhaps, excystment, could account for the sedimentation pattern seen.

\section{Conclusions}

The trophic role of the sarcodines, and in particular the acantharia, has only recently received adequate attention. Acantharia have long been known to possess symbiotic algae and thus contribute to net photosynthesis in the euphotic zone. Michaels (1988), using symbiont production rates from the literature, estimated that vegetative acantharians in the euphotic zone may account for up to $20 \%$ of primary production. The investigation of other modes of nutrition, however, has only recently been quantified. Swanberg and Caron (1991) found that acantharia feed preferentially on ciliated protozoa, in particular tintinnids, and small metazoans in a mixed plankton assemblage. Numbers of ciliates (predominantly naked forms) in the euphotic zone were high, ranging between 5000 and 10000 ind. $\mathrm{m}^{-3}$ (Antia, 1991), and were found mainly in the upper $30 \mathrm{~m}$ of the water column. Copepod nauplii and small metazoans $(<200 \mu \mathrm{m})$ were also present in the upper $50 \mathrm{~m}$, forming a potential food source for the acantharia.

The confinement of vegetative acantharia in our study almost exclusively to the upper $50 \mathrm{~m}$ of the water column could thus be a response to available microzooplankton nutrition and/or an adaptation to autotrophic symbiosis. Under light microscopy, we saw numerous (30-50) reddish droplets, 5-6 $\mu \mathrm{m}$ in diameter, within individual acantharia. When stained with DAPI, a DNAspecific dye, these were seen to contain nuclear material, implying that they were either nuclei of the acantharia or their endosymbionts. However, under UV excitation we were not able to distinguish individual chloroplasts of the symbiotic algae, but observed, rather, a diffuse red autofluorescence within the cysts. We are not sure whether this was caused by refraction within the cyst walls or the digestion of the symbionts. Many protozoans are known to stop feeding and shed or digest their symbionts during reproduction and cyst formation, which may account for our observations. Moreover, we did not observe 
acantharia feeding in our live samples and their trophic role during this investigation remains unquantified.

Reports on the sedimentation of acantharians are rare, primarily due to the rapid dissolution of $\mathrm{SrSO}_{4}$ in seawater after the death of the organisms (Schewiakoff, 1902). Acantharia are the only organisms known to precipitate strontium from seawater (aside from a minor contribution from coccolithophorid ooze and foraminifera), and are thought to play a role in the geochemical cycle of strontium in the oceans. Owing to the larger size of cysts found in this study, their contribution to strontium fluxes may be expected to exceed that reported by Bernstein et al. (1987) in the North Pacific. Measurements of dissolved and particulate $\mathrm{Sr}$ in samples from our cruise are underway and will be reported elsewhere.

From the data presented here, however, it is evident that acantharia can contribute substantially to particle sedimentation out of the upper ocean layers. During the drift experiment reported here, the contribution of acantharian cysts to total sedimenting matter collected in sediment traps below the euphotic zone exceeded by almost two orders of magnitude their relative contribution to suspended particulate matter. In order to evaluate their contribution to vertical carbon fluxes, it is of interest to know at which water depth release of carbon from their cysts occurs. Vegetative acantharia and freshly formed cysts ensure a structural integrity of spines and cyst walls, and dissolution may primarily occur subsequent to excystment and death. The partitioning of organic carbon between the cell cytoplasm and hard parts. (in the form of an organic matrix upon which strontium is deposited) is uncertain and hampers our understanding of the processes leading to the release of organic material from sinking cysts.

Studies of the vertical flux of organic matter in the ocean have been numerous in the past decades (Smetacek, 1980; Honjo, 1982; v.Bodungen et al., 1986) and it it recognized that the quality and quantity of sedimenting material is controlled largely by trophic interactions within the upper water column (e.g. Bathmann et al., 1990). The primary vehicles of vertical transport are large particles (McCave, 1975; Bishop et al., 1977) such as faecal pellets (Dunbar and Berger, 1981), hard parts of pelagic organisms (Bathmann et al., 1991) and large phytodetrital aggregates (Alldredge and Silver, 1988) which can form an important periodic source of food to organisms on the sea bed (Lampitt, 1985; Graf, 1990). The role of single groups of organisms in causing short, intense pulses of organic matter sedimentation has been documented (v.Bodungen et al., 1987; Bathmann, 1988; Bathmann et al., 1991). We report here on one such group which undergoes complete degradation within the winter mixed layer, but can nonetheless form a major part of organic matter sedimentation in shallow traps.

A drift experiment similar to that reported here was conducted at an adjacent station during June/July 1989, during which time primary production in the euphotic zone exceeded by a factor of three that measured in this study. Daily organic carbon sedimentation at the base of the euphotic zone amounted to $0.05 \%$ overlying suspended POC in 1989 , in contrast to $0.23 \%$ during August September 1990. Much of this material could be accounted for by the organic 
carbon contained in acantharian cysts (average $51 \%$ ), illustrating the importance of this single group of organisms in the measurement of vertical particle flux. By their mass occurrence and sedimentation, and absence in deeper water layers and at the sea bottom, acantharia may play an important role in the release of dissolved organic matter in mid-water layers. During the 9 day drift experiment reported here, sedimentation rates were high in relation to primary production in the euphotic zone (Antia et al., 1990), showing a temporal decoupling between production and export. The effect of acantharia in accentuating export from the upper water layers is special in terms of their dual trophic role as autoand heterotrophs (which they share with other pelagic protozoa such as foraminifera), and unique in terms of the ephemeral nature of their skeletons - and cyst walls.

Our observations pose some unanswered questions. Firstly, to what extent do acantharia contribute to productivity and/or heterotrophy in the euphotic zone? The mass occurrence of these organisms at a time when both algal productivity and algal biomass was low (Antia et al., 1990) suggests an adaptability to a late summer situation. Secondly, what significance does this encystment event have in the open ocean where, unlike in shallow coastal areas, vertical mixing cannot help repopulate the pelagial when conditions are favourable? The release of spores within the winter mixed layer, where they would be mixed to the surface on an annual basis would, on the other hand, confer an advantage to the acantharia, allowing for growth when conditions become favourable. The cysts found in this study appear not to be resting spores, but rather a means of reproduction, although the significance of a growing population at a time when the diel light period was short and pelagic biomass low is uncertain. The large numbers of acantharia that we found, however, indicate their importance in the euphotic zone and further investigation of their trophic behaviour clearly merits attention.

\section{Acknowledgements}

We thank P.C.Ried and A.W.John for kindly allowing us access to their unpublished manuscript. Our thanks to W.Koeve and two anonymous reviewers for constructive comments on the manuscript. C.Samtleben, U.Schuldt and H.Riemann are thanked for providing access to and help with the scanning electron microscopy, EDAX analysis and photographs. We acknowledge the skilful work of $M$.Wunsch who split the sediment trap samples. The captain and crew of the FS POSEIDON are thanked for their support during the cruise. This work was part of the Sonderforschungsbereich 313 of the University of Kiel, FRG, and was financed by the Deutsche Forschungsgemeinshaft. It is contribution No. 147 of the Sonderforschungsbereich 313 der Universität Kiel.

\section{References}

Alldredge,A.L. and Silver,M. (1988) Characteristics, dynamics and significance of marine snow. Prog. Oceanogr., 20, 41-82.

\section{2}


Antia,A.N. (1991) Microzooplankton in the pelagic food web of the East Greenland Sea and its role in sedimentation processes. PhD Thesis, Kiel University, pp. 109.

Antia.A.N., Bauerfeind,E., Bodungen,B.V., Hassan,M., Humborg,C., Kónig,H., Koeve,W., Langmaack,H., Machado,E., Peeken,I., Petersen,H., Podewski,S., Przygodda,K., Scholten,J., Voss, M. and Wunsch,M. (1990) The pelagic system and vertical particle flux during autumn in the Greenland Sea, Jan Mayen Current. Ber. Sonderforschungsbereich 313, 26, 1-54.

Bathmann,U.V. (1988) Mass occurrence of Salpa fusiformis in the spring of 1984 off Ireland: implications for sedimentation processes. Mar. Biol., 97, 127-135.

Bathmann,U.V., Peinert,R., Noji,T.T. and v.Bodungen,B. (1990) Pelagic origin and fate of sedimenting particles in the Norwegian Sea. Prog. Oceanogr., 24, 117-125.

Bathmann,U.V., Noji,T.T. and V.Bodungen,B. (1991) Sedimentation of pteropods in the Norwegian Sea in autumn. Deep-Sea Res., 38, 1341-1360.

Beers,J.R. and Stewart,G.L. (1970) The preservation of acantharians in fixed plankton samples. Limnol. Oceanogr., 15, 825-827.

Beers,J.R. and Stewart,G.L. (1971) Micro-zooplankton in the plankton communities in the upper waters of the eastern tropical Pacific. Deep-Sea Res., 18, 861-883.

Beers,J.R., Reid,M.H. and Stewart,G.L. (1975) Microplankton of the North Pacific Gyre. Population structure and abundance, June 1973. Int. Rev. Ges. Hydrobiol., 60, 607-638.

Bernstein,R.E., Betzer,P.R., Feely,R.A., Byme,R.H., Lamb,M.F. and Michaels,A.F. (1987) Acantharian fluxes and strontium to chlorinity ratios in the North Pacific Ocean. Science 237. 1490-1494.

Bishop,J.K.B., Edmond,J.M., Ketten,D.R., Bacon,M.P. and Silker,W.B. (1977) The chemistry, biology, and vertical flux of particulate matter from the upper $400 \mathrm{~m}$ of the equatorial Atlantic Ocean. Deep-Sea Res., 24, 511-548.

v. Bodungen, B. (1986) Phytoplankton growth and krill grazing during Spring in the Bransfield Strait, Antarctica-Implications from sediment trap collections. Polar Biol., 6, 153-160.

v. Bodungen,B., Smetacek,V.S., Tilzer,M.M. and Zeitzschel,B. (1986) Primary production and sedimentation during spring in the Antaretic peninsula region. Deep-Sea Res., 33, 177-184.

v. Bodungen,B., Fischer,G., Nöthig,E.-M. and Wefer,G. (1987) Sedimentation of krill faeces during spring development of phytoplankton in Bransfield Strait, Antarctica. Mitt. Geol.-Palaeontol. Inst. Univ. Hamburg, 62(S), 243-257.

v.Bodungen,B., Wunsch,M. and Fürderer,H. (1991) Sampling and analysis of suspended and sinking particles in the northern North Atlantic. In Marine Particles: Analysis and Characterisation. pp. 47-56.

Bottazzi,E.M. (1973) Ulteriori ritrovamenti di cisti di Acantari (Protozoa). Ist. Lomb. Sci. Lett., $107(B), 3-26$.

Bottazzi,E.M. and Andreoli,M.G. (1982) Distribution of acantharia in the western Sargasso Sea in correspondence with 'thermal fronts'. J. Protozool., 29, 162-169.

Bottazzi,E.M. and Vannucci,A. (1965) Acantharia in the Atlantic Ocean. A systematic and ecological analysis of plankton collections made during cruise 89 of R.V.Crawford of the Woods Hole Institution. 3rd Contribution. Arch. Oceanogr. Limnol., 14, 154-257.

Buesseler,K.O. (1991) Do upper ocean sediment traps provide an accurate record of particle flux? Nature, 353, 420-423.

Cachon,J. and Cachon,M. (1985) Actinopoda. In Lee,J.J., Hunter,S.H. and Bovee, E.C. (eds), An Illustrated Guide to the Protozoa. Allen Press Inc., Kansas, pp. 274-283.

Dunbar,R.B. and Berger,W. (1981) Faecal pellet flux to modern bottom sediments of Santa Barbara Basin (California) based on sediment trapping. Bull. Geol. Soc. Am., 92, 212-218.

Graf,G. (1991) Benthic-pelagic coupling in a deep-sea benthic community. Nature, 341, 437-439.

Haeckel,E. (1887) Report on the Radiolaria collected by H.M.S. Challenger during the years 18731876. First part-Porulosa. (Spumellaria and Acantharia). Rep. Sci. Results Voyage HMS Challenger (s. Zool.), 18, 1-1803.

Hargrave,B.T., v.Bodungen,B., Stoffyn-Egli,P. and Mudie,P.J. (1992) Seasonal variability in particle sedimentation under permanent ice cover in the Arctic Ocean. Continensal Shelf Res., 12, in press.

Hollande,A. and Cachon-Enjumet,M. (1957) Enksystement et reproduction isosporogénétique chez les acanthaires. C.R. Acad. Sci., 244, 508-510.

Hollande,A., Cachon,J. and Cachon-Enjumet,M. (1965) Les modalités de le'enkystement presporangénétique chez les acanthaires. Protistologica, 1, 91-112.

Honjo,S. (1982) Seasonality and interaction of biogenic and fithogenic particulate flux at the Panama Basin. Nature, 218, 883-884. 
A.N.Antia et al.

Lampitt,R.S. (1985) Evidence for the seasonal deposition of detritus to the deep-sea floor and its subsequent resuspension. Deep-Sea Res., 32, 885-897.

McCave,I.N. (1975) Vertical flux of particles in the ocean. Deep-Sea Res., 22, 491-502.

Michaels,A.F. (1988) Vertical distribution and abundance of Acantharia and their symbionts. Mar. Biol., 97, 559-569.

Michaels,A.F. (1991) Acantharian abundance and symbiont productivity at the VERTEX seasonal station. J. Plankton Res., 13, 399-418.

Schewiakoff,W. (1902) Beiträge zur Kentnis der Radiolaria Acanthometra. Mem. Acad. Imp. Sci. St. Petersbourg, XII, 1-40.

Schewiakoff,W. (1926) Die Acantharia des Golfes von Neapel. Flora Fauna Golfes Neapel, 37, 1755.

Smetacek,V. (1980) Annual cycle of sedimentation in relation to phytoplankton ecology in the western Kiel Bight. Ophelia Suppl., 1, 65-76.

Spindler,M. and Beyer,K. (1990) Distribution, abundance and diversity of Antarctic acantharian cysts. Mar. Micropalaeontol., 15, 209-218.

Swanberg,N.R. and Caron,D.A. (1991) Patterns of feeding in epipelagic oceanic plankton. J. Plankton Res., 13, 287-312.

Zeitzschel,B., Diekmann,P. and Uhimann,L. (1978) A new multisample sediment trap. Mar. Biol, 45, 285-288

Received on February 2, 1992; accepted on October 6, 1992 